\title{
Peningkatan pemahaman hukum bagi masyarakat dalam pengendalian kebakaran hutan dan lahan di Desa Petapahan Kecamatan Tapung Kabupaten Kampar
}

\author{
Syaifullah Yophi Ardiyanto*, Setia Putra, Tengku Arif Hidayat, Muhammad A. Rauf, \& \\ Samariadi
}

Universitas Riau

*Syaifullahyophi23@gmail.com

\begin{abstract}
Abstrak. Provinsi Riau sebagai salah satu provinsi di Indonesia dengan persoalan kebakaran hutan dan lahan yang selalu terjadi setiap tahun. Perlunya pemahaman dan peran serta dari berbagai pihak tidak hanya pemerintah tetapi juga masyarakat dalam pengendalian kebakaran hutan lahan agar kebakaran hutan lahan tidak lagi terjadi di Provinsi Riau sesuai Instruksi Presiden Nomor 3 Tahun 2020 tentang Penanggulangan Kebakaran Hutan dan Lahan. Oleh karena itu perlunya kegiatan peningkatan peran serta dan pemahaman hukum bagi masyarakat dalam pengendalian kebakaran hutan dan lahan di Provinsi Riau khususnya Desa Petapahan Kecamatan Tapung Kabupaten Kampar. Kegiatan Pengabdian ini bertujuan untuk penguatan peningkatan peran serta dan pemahaman hukum bagi masyarakat dalam pengendalian kebakaran hutan dan lahan (KARHUTLA). Metode pengabdian dilaksanakan dengan delapan tahap kegiatan: (1) Analisa Permasalahan; (2) Identifikasi Permasalahan; (3) Perumusan Masalah; (4) Pengembangan Alternatif Pemecahan; (5) Pemilihan alternatif terbaik, (6) Perancangan aplikasi, (7) Implementasi; dan (8) Pengujian. Dari kegiatan pengabdian diperoleh hasil peningkatan pengetahuan dan pemahaman hukum peserta pengabdian mengenai pengendalian dan penanggulangan kebakaran hutan dan lahan. Dari sisi ekonomi kegiatan ini berguna untuk masyarakat sekitar hutan agar dapat menikmati hasil hutan yang mereka kelola dengan harapan ada peningkatan ekonomi yang stabil dan menciptakan lapangan kerja bagi generasi mendatang
\end{abstract}

Kata kunci: hutan, lahan, kebakaran, hukum, masyarakat

Abstract. Riau Province is one of the provinces in Indonesia with the problem of forest and land fires that always occur every year. There is a need for understanding and participation from various parties, not only the government but also the community in controlling land forest fires so that land forest fires no longer occur in Riau Province according to Presidential Instruction No.3 of 2020 concerning Forest and Land Fire Management. Therefore, there is a need for activities to increase the role and understanding of the law for the community in controlling forest and land fires in Riau Province, especially in Petapahan Village, Tapung District, Kampar Regency. The service method is carried out using the waterfall model with eight stages of activity: (1) Problem Analysis; (2) Problem Identification; (3) Problem Formulation; (4) Development of Alternative Solutions; (5) Selection of the best alternative, (6) Application design, (7) Implementation; and (8) Testing. From these service activities, it was obtained as the result of an increase in the knowledge and understanding of the law of the community service participants regarding the control and handling of forest and land fires. This activity is carried out by evaluating the service participants by asking questions related to the service material that has been carried out. From an economic point of view, this activity is useful for communities around the forest so that they can enjoy the forest products they manage in the hope that there will be a stable economic increase and create jobs for future generations.

Keywords: forest, land, fire, law, community

To cite this article: Ardiyanto, S. Y., S. Putra., T. A. Hidayat., M. A. Rauf., \& Samariadi. 2020. Peningkatan pemahaman hukum bagi masyarakat dalam pengendalian kebakaran hutan dan lahan di Desa Petapahan Kecamatan Tapung Kabupaten Kampar. Unri Conference Series: Community Engagement 2: 393-401. https://doi.org/10.31258/unricsce.2.393-401

(C) 2020 Authors

Peer-review under responsibility of the organizing committee of Seminar Nasional Pemberdayaan Masyarakat 2020 


\section{PENDAHULUAN}

Hutan sebagai karunia Tuhan Yang Maha Esa merupakan modal pembangunan nasional yang memiliki manfaat yang nyata baik bagi kehidupan dan penghidupan bangsa Indonesia, hutan bermanfaat bagi ekologi, sosial budaya dan ekonomi untuk masyarakat Indonesia. Oleh karena itu hutan harus diurus dan dikelola oleh pemerintah dan masyarakat. Hutan seharusnya dilindungi serta dimanfaatkan secara berkesinambungan dan berkelanjutan bagi kesejahteraan masyarakat, tidak hanya untuk generasi sekarang tetapi juga untuk generasi yang akan datang.

Namun sangat disayangkan, kondisi hutan Indonesia pada saat ini sudah sangat memprihatinkan, hal ini disebabkan oleh laju deforestasi hutan yang tinggi di setiap tahunnya dan tidak sebanding dengan kecepatan pelaksanaan rehabilitasi hutan dan lahan, termasuk penghijauan, reforestasi dan reklamasi oleh berbagai pihak, baik pemerintah, swasta maupun masyarakat. Kondisi ini diperburuk dengan terjadinya kebakaran hutan dan lahan di berbagai tempat sehingga mengakibatkan terjadinya penurunan keanekaragaman hayati secara signifikan. Juga berakibat buruk pada kesehatan masyarakat dan lingkungan.

Kebakaran hutan dan lahan bisa terjadi baik disengaja maupun tanpa disengaja. Dengan kata lain, terjadinya kebakaran hutan dan lahan dapat diakibatkan oleh faktor kesengajaan manusia melalui beberapa kegiatan, seperti kegiatan perladangan, perkebunan, HTI, penyiapan lahan untuk ternak sapi, dan sebagainya. Faktor kebakaran hutan dan lahan karena kesengajaan ini merupakan faktor utama (90\%) penyebab kebakaran hutan dan lahan yang terjadi saat ini (Purbowaseso 2004).

Kebakaran hutan dan lahan antara lain karena faktor alam, biasanya terjadi pada musim kemarau ketika cuaca sangat panas dan faktor pembakaran oleh manusia. Sebab utama dari kebakaran adalah pembukaan lahan yang meliputi; (1) Pembakaran lahan yang tidak terkendali; (2) Penggunaan lahan yang menjadikan lahan rawan kebakaran; (3) Konflik antara pihak pemerintah, perusahaan dan masyarakat karena status lahan sengketa perusahaan-perusahaan kelapa sawit kemudian menyewa tenaga kerja dari luar untuk bekerja dan membakar lahan masyarakat lokal yang lahannya ingin diambil alih oleh perusahaan guna mengusir masyarakat; (4) Dalam beberapa kasus, penduduk lokal juga melakukan pembakaran untuk memprotes pengambil alihan lahan mereka oleh perusahaan kelapa sawit; (5) Tingkat pendapatan masyarakat yang relatif rendah, sehingga terpaksa memilih alternatif yang mudah, murah dan cepat untuk pembukaan lahan; (6) Kurangnya penegakan hukum terhadap individu dan perusahaan yang melanggar peraturan pembukaan lahan; (7) Faktor alam seperti sambaran petir, lahar dari letusan gunung dan lain-lain. (Desri Hunawan, 2016).

Kerugian akibat kebakaran hutan dan lahan sangat besar terhadap kehidupan manusia maupun terhadap kehidupan makhluk hidup lainnya baik secara langsung maupun tidak langsung, antara lain: (1) Dampak Ekologi; (2) Dampak Ekonomi; dan (3) Dampak Kesehatan (Desri Hunawan, 2016). Kebakaran hutan dan lahan terus saja terjadi, walaupun secara peraturan perundang-undangan sudah ada peraturan yang mengatur sanksi bagi pembakar hutan dan lahan, namun hal ini tidak membuat masyarakat atau perusahaan berhenti untuk melakukan pembakaran. Sebagaimana diatur dalam: (1) Kitab Undang-Undang Hukum Pidana (KUHP), Pasal 187 dan Pasal 188; (2) Undang-Undang Nomor 32 Tahun 2009 tentang Perlindungan dan Pengelolaan Lingkungan Hidup, Pasal 69 ayat (1) dan Pasal 108; (3) Undang-Undang Nomor 19 Tahun 2004 tentang Penetapan Peraturan Pemerintah Pengganti Undang-Undang Nomor 1 Tahun 2004 tentang Perubahan atas Undang-Undang Nomor 41 Tahun 1999 tentang Kehutanan menjadi Undang-Undang, Pasal 50 ayat (3) huruf d, Pasal 78 ayat (2) dan (3); dan (4) Undang-Undang Nomor 18 Tahun 2004 tentang Perkebunan, Pasal 26 dan Pasal 48 ayat (1) dan (2).

Bahkan pada tahun 2015 Presiden menerbitkan Instruksi Presiden Nomor 11 Tahun 2015 tentang Peningkatan Pengendalian Kebakaran Hutan dan Lahan, yang mana dalam instruksi tersebut diperintahkan Kepada Menteri Koordinator, Menteri Negara, Kepala Badan setingkat Menteri, Pemerintah Daerah dan lainnya untuk menjadikan permasalahan kebakaran hutan dan lahan sebagai prioritas permasalahan yang diselesaikan melalui tiga pendekatan, yaitu: (1) pencegahan terjadinya kebakaran hutan dan lahan; (2) pemadaman kebakaran hutan dan lahan; dan (3) penanganan pasca kebakaran atau pemulihan hutan dan lahan. Kemudian pada tahun 2020, Presiden kembali menerbitkan Instruksi Presiden Nomor 3 Tahun 2020 tentang Penanggulangan Kebakaran Hutan dan Lahan menggantikan Instruksi Presiden Nomor 11 Tahun 2015 tentang Peningkatan Pengendalian Kebakaran Hutan dan Lahan. Dalam Instruksi Presiden Nomor 3 Tahun 2020 tentang Penanggulangan Kebakaran Hutan dan Lahan tersebut menginstruksikan: (1) melakukan upaya penanggulangan kebakaran hutan dan lahan di seluruh wilayah Republik Indonesia yang meliputi kegiatan : (a) pencegahan terjadinya kebakaran hutan dan lahan; (b) pemadaman kebakaran hutan dan lahan; dan (3) penanganan pasca kebakaran hutan dan lahan. (2) mengefektifkan upaya penegakan hukum terhadap tindak 
pidana kebakaran hutan dan lahan sekaligus pembayaran ganti rugi sesuai dengan tingkat kerusakan atau akibat yang dibutuhkan untuk biaya rehabilitasi, pemulihan kondisi hutan dan lahan, atau tindakan lain yang diperlukan serta pengenaan sanksi administrasi sesuai ketentuan peraturan perundang-undangan.

Provinsi Riau sebagai salah satu provinsi di Indonesia dengan persoalan lingkungan hidup yang cukup kompleks, khususnya persoalan kerusakan hutan dan ekosistem gambut yang dampaknya sebagai salah satu provinsi penyumbang terbesar bencana kebakaran hutan dan lahan yang terjadi di Indonesia. Pasca diterbitkannya Instruksi Presiden Republik Indonesia Nomor 11 Tahun 2015 Tentang Peningkatan Pengendalian Kebakaran Hutan dan Lahan memang kebakaran hutan dan lahan di Riau mengalami penurunan signifikan. Namun sayangnya, upaya prioritas berupa pencegahan yang seharusnya dilakukan oleh pemerintah, masyarakat dan pihak swasta belum mampu mampu menyelesaikan akar permasalahan kebakaran hutan dan lahan di ekosistem gambut di Provinsi Riau terutama di Desa Petapahan Kecamatan Tapung Kabupaten Kampar yang terus saja terjadi sampai saat ini.

Keberadaan hutan di Provinsi Riau sudah sangat mengkhawatirkan. Berdasarkan temuan Jaringan Kerja Penyelamat Hutan Riau (Jikalahari) mengemukakan bahwa (Jikalahari dalam 14 Tahun Melawan Monopoli Pengusaha Hutan dan Lahan, 2016): Pengelolaan hutan di Provinsi Riau selama ini yang menimbulkan begitu banyak permasalahan pertama, mulai dari deforestasi-degradasi hutan Riau, kedua, konflik dengan masyarakat tempatan dan pencemaran/kerusakan lingkungan hidup terjadi sejak korporasi hutan tanaman industri dan perkebunan kelapa sawit beroperasi, ketiga, kerusakan hutan di Riau mengakibatkan banjir setiap musim hujan, kebakaran hutan selalu terjadi saban kemarau dan keempat praktik korupsi merupakan awal pintu masuk praktek monopoli dan berujung pada kerusakan ekologis. Praktek pengelolaan hutan selama ini yang semestinya bisa menjamin kelestarian hutan alam di Riau tidak terlaksana, namun sebaliknya pengelolaan hutan yang berlangsung justru semakin mengancam keberadaan hutan dan masyarakat Riau. Bencana banjir, kebakaran hutan dan lahan yang melanda Provinsi Riau merupakan suatu bukti bahwa hutan Riau yang ada saat ini tidak lagi dapat menjaga keseimbangan lingkungan. Slogan pengelolaan hutan untuk kesejahteraan masyarakat, pada kenyataannya yang terjadi justru sebaliknya. Kantong-kantong kemiskinan justru berada pada daerah-daerah di dalam dan di sekitar kawasan hutan.

Kebakaran hutan dan lahan pada tahun 2014-2015 tersebut mengakibatkan 5 orang meninggal, lebih dari 90 ribu jiwa terkena Infeksi Saluran Pernapasan Akut (ISPA) hingga aktivitas pendidikan dan perekonomian yang terganggu karenanya (Walhi Riau, 2018). Kebakaran hutan dan lahan saat ini terjadi di Provinsi Riau, dimana lokasi kebakaran kebanyakan terjadi di lahan gambut, sehingga pemadaman sulit dilakukan. Selain minimnya sumber air, akses untuk menjangkau titik api juga sulit dilalui. Kemudian ditambah cuaca panas, serta kabut asap pekat di lokasi membuat pemadaman kebakaran memakan waktu yang lama. (Kompas, 11 Agustus 2019). Berikut rekapitulasi luas kebakaran hutan dan lahan di Provinsi Riau hingga 11 Agustus 2019, sebagaimana tabel di bawah ini:

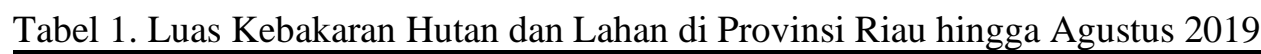

\begin{tabular}{lcc}
\hline No. & Kabupaten/Kota & Luas Hutan dan Lahan yang Terbakar (Ha) \\
\hline 1 & Bengkalis & 1.542 .08 \\
2 & Rokan Hulu & 8.25 \\
3 & Rokan Hilir & 1.018 .45 \\
4 & Dumai & 310.75 \\
5 & Kepulauan Meranti & 252.70 \\
6 & Siak & 671.90 \\
7 & Pekanbaru & 93.23 \\
8 & Kampar & 138.28 \\
9 & Pelalawan & 206
\end{tabular}




\begin{tabular}{ccc}
\hline No. & Kabupaten/Kota & Luas Hutan dan Lahan yang Terbakar (Ha) \\
\hline 10 & Indragiri Hulu & 114 \\
11 & Indragiri Hilir & 563.85 \\
12 & Kuansing & 5.1 \\
\hline
\end{tabular}

Sumber: Kompas, 11 Agustus 2019, Data Olahan 2019

Kebakaran hutan yang terus saja terjadi memberikan banyak kerugian tidak hanya dari sisi ekonomi, sosial tetapi juga lingkungan. Pada tahun 2015 saja kebakaran hutan yang terparah saat itu terjadi menurut Deputi Perencanaan dan Kerjasama Badan Restorasi Gambut (BRG) Budi Wardhana, bahwa kebakaran hutan di lahan gambut telah menimbulkan kerugian ekonomi yang besar. Berdasarkan data Bank Dunia, saat kebakaran lahan besar-besaran terjadi tahun 2015 lalu, nilai kerugian pemerintah mencapai Rp2,5 triliun. Jumlah kerugian itu belum termasuk dampak buruk bagi kesehatan masyarakat, terhentinya proses produksi, terganggunya kegiatan perdagangan dan transportasi, serta menurunnya nilai sumber daya di daerah terdampak. Jika ditotal, estimasi kerugian bisa membengkak hingga Rp 221 triliun (Tempo, 13 Agustus 2019). Hal ini juga diperparah dengan bahwa selama ini, masyarakat masih diizinkan melakukan pembakaran demi membuka lahan di kawasan gambut maksimal 2 hektar. Namun, pengawasan atas pembakaran tersebut seringkali tidak maksimal bahkan bertentang dengan peraturan perundang-undangan yang berlaku, sehingga akhirnya menimbulkan kebakaran hutan dan lahan. Lahan gambut merupakan kawasan yang rentan terjadi bencana kebakaran apabila dikeringkan. Kawasan bergambut dilindungi dalam Keputusan Presiden Nomor 32 Tahun 1990 tentang Pengelolaan Kawasan Lindung, memberikan pengaturan yang cukup mendasar terhadap ekosistem gambut, yaitu ketentuan mengenai kedalaman gambut yang perlu dilindungi. Dalam Keputusan Presiden tersebut diatur, bahwa gambut dengan kedalaman lebih dari 3 Meter atau lebih yang terdapat di bagian hulu sungai dan rawa harus dilindungi. Pengaturan itu diperkuat lagi dengan Peraturan Pemerintah Nomor 71 Tahun 2014 tentang Perlindungan dan Pengelolaan Ekosistem Gambut jo Peraturan Pemerintah Nomor 57 Tahun 2016 tentang Perubahan atas Peraturan Pemerintah Nomor 71 Tahun 2014 Tentang Perlindungan dan Pengelolaan Ekosistem Gambut. Pemerintah bisa mencarikan alternatif pembersihan lahan tanpa metode pembakaran, misalnya program pembukaan sawah menggunakan mikroba. praktik pembakaran lahan seharusnya menjadi pilihan terakhir bagi masyarakat dalam membuka lahan untuk produksi.

Hal ini juga berkaitan dengan perlunya peningkatan pemahaman pengetahuan masyarakat dalam memahami aspek hukum pengelolaan hutan dan lahan berdasarkan peraturan perundang-undangan yang berlaku. Merevisi peraturan perundang-undangan saja tidak akan memecahkan masalah kebakaran hutan, walaupun itu salah satu cara, tetapi lebih kepada penyadaran hukum kepada masyarakat selaku pengelola hutan dan lahan itu lebih penting agar mematuhi peraturan perundang-undangan dengan tidak melakukan pembakaran hutan. Serta hukum perlu ditegakkan apabila terjadi pelanggaran. Hal ini dirasa masih sangat lemah baik dari sisi pengawasan maupun penegakan hukum. Oleh karena itu berkaitan dengan Instruksi Presiden Nomor 11 Tahun 2015 dirasa sangat perlu untuk melakukan pengabdian kepada masyarakat berkaitan dengan "Penguatan Peningkatan Peran Serta dan Pemahaman Hukum bagi Masyarakat dan Pemangku Kepentingan dalam Pengendalian Kebakaran Hutan dan Lahan (Karhutla) di Desa Petapahan Kecamatan Tapung Kabupaten Kampar". Kegiatan Pengabdian ini bertujuan untuk penguatan peningkatan peran serta dan pemahaman hukum bagi masyarakat dalam pengendalian kebakaran hutan dan lahan (KARHUTLA).

\section{METODE PENERAPAN}

Berikut ini ditampilkan metode penerapan pengabdian:

1. Alat dan Bahan yang Digunakan

Wawancara, Penyuluhan Hukum dan perumusan Kebijakan peningkatan pengendalian kebakaran hutan dan lahan di di Desa Petapahan Kecamatan Tapung Kabupaten Kampar

2. Unsur Pelaksana dan Peserta

Pelaksana terdiri dari:

a. Pemerintah Desa Petapahan Kecamatan Tapung Kabupaten Kampar

b. Penyuluh

c. Moderator 
Peserta terdiri dari:

a. Masyarakat di Desa Petapahan Kecamatan Tapung Kabupaten Kampar

b. Tokoh Masyarakat Adat

c. Lembaga Swadaya Masyarakat sebagai pemerhati lingkungan hidup dan kehutanan

Rangkaian Kegiatan yang dilakukan:

a. Pemberian pertanyaan tentang peningkatan pengendalian kebakaran hutan dan lahan di Desa Petapahan Kecamatan Tapung Kabupaten Kampar

b. Wawancara dengan Pemerintah dan stakeholders terkait

c. Penyampaian materi dalam bentuk ceramah dan tatap muka tentang peningkatan pengendalian kebakaran hutan dan lahan di Desa Petapahan Kecamatan Tapung Kabupaten Kampar

d. Penyuluhan Hukum tentang pengendalian kebakaran hutan dan di Desa Petapahan Kecamatan Tapung Kabupaten Kampar

e. Perumusan Kebijakan peningkatan pengendalian kebakaran hutan dan lahan di Desa Petapahan Kecamatan Tapung Kabupaten Kampar

Metode penerapan yang akan dilaksanakan adalah metode air terjun (waterfall model) dengan delapan tahap kegiatan dimulai dari beberapa tahapan-tahapan:

1. Analisa Permasalahan

2. Identifikasi Permasalahan

3. Perumusan Masalah

4. Pengembangan Alternatif Pemecahan

5. Pemilihan alternatif terbaik

6. Perancangan aplikasi

7. Implementasi

8. Pengujian

\section{HASIL DAN KETERCAPAIAN SASARAN}

Pemerintah Provinsi Riau telah menetapkan status siaga darurat Karhutla sejak 11 Februari 2020 hingga 31 Oktober 2020 mendatang, penetapan status siaga bertujuan untuk mempercepat gerak tim Karhutla dan datangnya bantuan dari pusat. Karena berdasarkan perkiraan BMKG Provinsi Riau akan mengalami kemarau panjang dan Riau termasuk daerah yang sebagian besar lahannya gambut membuat Riau semakin rawan Karhutla.

Kepala Badan Nasional Penanggulangan Bencana (BNPB) Letjen TNI Doni Monardo menjelaskan Penyebab Karhutla 99\% adalah ulah manusia, sementara 80\% kebakaran lahan itu sendiri, datanya 1,6 juta Hektar Kebakaran lahan pada tahun yang lalu, dan Provinsi Riau berada di posisi ketujuh dan luas lahan gambut yang terbakar seluas 62 ribu hektar. Lahan gambut yang terbakar sangat sulit dipadamkan, bulan Agustus tahun lalu merupakan titik api tertinggi untuk Riau (Diskominfo, 20 Maret 2020).

Bahkan pada tahun 2015 Presiden menerbitkan Instruksi Presiden Nomor 11 Tahun 2015 tentang Peningkatan Pengendalian Kebakaran Hutan dan Lahan, yang mana dalam instruksi tersebut diperintahkan Kepada Menteri Koordinator, Menteri Negara, Kepala Badan setingkat Menteri, Pemerintah Daerah dan lainnya untuk menjadikan permasalahan kebakaran hutan dan lahan sebagai prioritas permasalahan yang diselesaikan melalui tiga pendekatan, yaitu : (1) pencegahan terjadinya kebakaran hutan dan lahan; (2) pemadaman kebakaran hutan dan lahan; dan (3) penanganan pasca kebakaran atau pemulihan hutan dan lahan.

Kemudian pada tahun 2020, Presiden kembali menerbitkan Instruksi Presiden Nomor 3 Tahun 2020 tentang Penanggulangan Kebakaran Hutan dan Lahan menggantikan Instruksi Presiden Nomor 11 Tahun 2015 tentang Peningkatan Pengendalian Kebakaran Hutan dan Lahan. Dalam Instruksi Presiden Nomor 3 Tahun 2020 tentang Penanggulangan Kebakaran Hutan dan Lahan tersebut menginstruksikan: (1) melakukan upaya penanggulangan kebakaran hutan dan lahan di seluruh wilayah Republik Indonesia yang meliputi kegiatan : (a) pencegahan terjadinya kebakaran hutan dan lahan; (b) pemadaman kebakaran hutan dan lahan; dan (3) penanganan pasca kebakaran hutan dan lahan. (2) mengefektifkan upaya penegakan hukum terhadap tindak pidana kebakaran hutan dan lahan sekaligus pembayaran ganti rugi sesuai dengan tingkat kerusakan atau akibat yang dibutuhkan untuk biaya rehabilitasi, pemulihan kondisi hutan dan lahan, atau tindakan lain yang diperlukan serta pengenaan sanksi administrasi sesuai ketentuan peraturan perundang-undangan. 
Berkaitan dengan hal tersebut diatas telah dilakukan kegiatan sosialisasi pentingnya Penguatan Peningkatan Peran Serta dan Pemahaman Hukum bagi Masyarakat dan Pemangku Kepentingan dalam Pengendalian Kebakaran Hutan dan Lahan (Karhutla) di Desa Petapahan Kecamatan Tapung Kabupaten Kampar. Penguatan Peningkatan Peran Serta dan Pemahaman Hukum bagi Masyarakat dan Pemangku Kepentingan salah satunya dilakukan dengan cara penyuluhan hukum peraturan perundang-undangang yang berkaitan dengan kebakaran hutan lahan terutama sanksi pidana bagi pelaku pembakar hutan lahan.

Kebakaran hutan dan lahan menimbulkan dampak terhadap kerusakan lingkungan, sosial dan kesehatan masyarakat. Tidak hanya sekedar musnahnya ekosistem tapi kabut asap yang ditimbulkannya mengganggu kesehatan masyarakat bahkan perekonomian juga ikut terganggu. Pembakaran hutan atau lahan merupakan kejahatan yang harus diperangi secara komprehensif oleh setiap pihak. salah satu upaya untuk membalas pelaku pembakaran hutan atau lahan adalah dengan mengenakan hukuman pidana penjara dan denda semaksimal mungkin, untuk membuat jera dan menjadi pelajaran bagi masyarakat dan oknum yang lain agar tidak melakukan pembakaran hutan lagi. Berikut peraturan perundang-undangan yang mengatur pasal tentang sanksi pidana bagi pelaku pembakar hutan dan lahan (M. Hariyanto):

\section{A. Undang-Undang No. 41 Tahun 1999 tentang Kehutanan}

Pasal 50 ayat (3) huruf d mengatur bahwa setiap orang dilarang membakar hutan. Pelanggaran hukum (bagi yang melakukan pembakaran hutan) terhadap Pasal Pasal 50 ayat (3) huruf d Undang-Undang Kehutanan tersebut diancam dengan sanksi pidana dan denda Sanksi sebagaimana diatur dalam Pasal 78 ayat (3) menerangkan pembakaran hutan dengan sengaja maka dikenakan pidana paling lama 15 tahun dan denda paling banyak Rp 5 miliar. Sedangkan pada ayat (4) pasal tersebut menyatakan pelanggar karena kelalaiannya diancam pidana 15 tahun dengan denda paling banyak Rp 1,5 miliar.

\section{B. Undang-Undang No. 32 Tahun 2009 Tentang Perlindungan dan Pengelolaan Lingkungan Hidup (UUPPLH)}

Kebakaran hutan atau kebakaran lahan juga dapat mengakibatkan pencemaran lingkungan hidup dan kerusakan lingkungan hidup sehingga dapat dikenai sanksi berdasarkan Perlindungan dan Pengelolaan Lingkungan Hidup yaitu:

Pasal 69 ayat (1): "Setiap orang dilarang melakukan pembukaan lahan dengan cara membakar"

Pasal 108 UUPPLH: "Setiap orang yang melakukan pembakaran lahan sebagaimana dimaksud dalam Pasal 69 ayat (1) huruf h, dipidana dengan pidana penjara paling singkat 3 (tiga) tahun dan paling lama 10 (sepuluh) tahun dan denda paling sedikit Rp3.000.000.000,00 (tiga miliar rupiah) dan paling banyak Rp10.000.000.000,00 (sepuluh miliar rupiah)"

Pasal 69 ayat (2): "Ketentuan sebagaimana dimaksud pada ayat (1) huruf h memperhatikan dengan sungguh sungguh kearifan lokal di daerah masing masing"

Penjelasan Pasal 69 ayat (2): "Kearifan lokal yang dimaksud dalam ketentuan ini adalah melakukan pembakaran lahan dengan luas lahan maksimal 2 hektar per kepala keluarga untuk ditanami tanaman jenis varietas lokal dan dikelilingi oleh sekat bakar sebagai pencegah penjalaran api ke wilayah sekelilingnya"

Pasal 98 ayat (1) UUPPLH

"Setiap orang yang dengan sengaja melakukan perbuatan yang mengakibatkan dilampauinya baku mutu udara ambien, baku mutu air, baku mutu air laut, atau kriteria baku kerusakan lingkungan hidup, dipidana dengan pidana penjara paling singkat 3 (tiga) tahun dan paling lama 10 (sepuluh) tahun dan denda paling sedikit Rp3.000.000.000,00 (tiga miliar rupiah) dan paling banyak Rp10.000.000.000,00 (sepuluh miliar rupiah)"

Pasal 98 ayat (2) UUPPLH

"Apabila perbuatan sebagaimana dimaksud pada ayat (1) mengakibatkan orang luka dan/atau bahaya kesehatan manusia, dipidana dengan pidana penjara paling singkat 4 (empat) tahun dan paling lama 12 (dua belas) tahun dan denda paling sedikit Rp4.000.000.000,00 (empat miliar rupiah)dan paling banyak Rp12.000.000.000,00 (dua belas miliar rupiah)"

Pasal 98 ayat (3) UUPPLH

"Apabila perbuatan sebagaimana dimaksud pada ayat (1) mengakibatkan orang luka berat atau mati, dipidana dengan pidana penjara paling singkat 5 (lima) tahun dan paling lama 15 (lima belas) tahun dan denda paling sedikit Rp5.000.000.000,00 (lima miliar rupiah) dan paling banyak Rp15.000.000.000,00 (lima belas miliar rupiah)"

Pasal 99 ayat (1): 
"Setiap orang yang karena kelalaiannya mengakibatkan dilampauinya baku mutu udara ambien, baku mutu air, baku mutu air laut, atau kriteria baku kerusakan lingkungan hidup, dipidana dengan pidana penjara paling singkat 1 (satu) tahun dan paling lama 3 (tiga) tahun dan denda paling sedikit Rp1.000.000.000,00 (satu miliar rupiah) dan paling banyak Rp3.000.000.000,00 (tiga miliar rupiah)"

Pasal 99 ayat (2):

"Apabila perbuatan sebagaimana dimaksud pada ayat (1) mengakibatkan orang luka dan/atau bahaya kesehatan manusia, dipidana dengan pidana penjara paling singkat 2 (dua) tahun dan paling lama 6 (enam) tahun dan denda paling sedikit Rp2.000.000.000,00 (dua miliar rupiah)dan paling banyak Rp6.000.000.000,00 (enam miliar rupiah)"

Pasal 99 ayat (3):

"Apabila perbuatan sebagaimana di maksud pada ayat (1) mengakibatkan orang luka berat atau mati, dipidana dengan pidana penjara paling singkat 3 (tiga) tahun dan paling lama 9 (sembilan) tahun dan denda paling sedikit Rp3.000.000.000,00 (tiga miliar rupiah) dan paling banyak Rp9.000.000.000,00 (sembilan miliar rupiah)"

Pasal 119 UUPPLH:

Selain pidana sebagaimana dimaksud dalam Undang-Undang ini, terhadap badan usaha dapat dikenakan pidana tambahan atau tindakan tata tertib berupa:

A. perampasan keuntungan yang diperoleh dari tindak pidana;

B. penutupan seluruh atau sebagian tempat usaha dan/atau kegiatan;

C. perbaikan akibat tindak pidana;

D. pewajiban mengerjakan apa yang dilalaikan tanpa hak; dan/atau

E. penempatan perusahaan di bawah pengampuan paling lama 3 (tiga) tahun

F. Undang-Undang No. 39 Tahun 2014 Tentang Perkebunan

Pasal 56 ayat (1):

"Setiap Pelaku Usaha Perkebunan dilarang membuka dan/atau mengolah lahan dengan cara membakar" Pasal 108:

"Setiap Pelaku Usaha Perkebunan yang membuka dan/atau mengolah lahan dengan cara membakar sebagaimana dimaksud dalam Pasal 56 ayat (1) dipidana dengan pidana penjara lama 10 (sepuluh ) tahun dan denda paling banyak Rp 10.000 .0 00.000,00 (sepuluh miliar rupiah)”

\section{Kitab Undang Undang Hukum Pidana (KUHP)}

\section{Pasal 187 KUHP}

"Barang siapa dengan sengaja menimbulkan kebakaran, ledakan atau banjir, diancam:

1. dengan pidana penjara paling lama dua belas tahun, jika karena perbuatan tersebut di atas timbul bahaya umum bagi barang;

2. dengan pidana penjara paling lama lima belas tahun, jika karena perbuatan tersebut di atas timbul bahaya bagi nyawa orang lain

3. dengan pidana penjara seumur hidup atau selama waktu tertentu paling lama dua puluh tahun, jika karena perbuatan tersebut di atas timbul bahaya bagi nyawa orang lain dan mengakibatkan orang mati.

Pasal 189 KUHAP:

"Barang siapa pada waktu ada atau aka nada kebakaran, dengan sengaja dan melawan hukum menyembunyikan atau membikin tak dapat dipakai perkakas-perkakas atau alat-alat pemadam api atau dengan cara apapun merintangi atau menghalang-halangi pekerjaan memadamkan api diancam dengan pidana penjara paling lama tujuh tahun"

Selain peraturan Perundang-undangan tersebut, Presiden menerbitkan Instruksi Presiden Nomor 3 Tahun 2020 tentang Penanggulangan Kebakaran Hutan dan Lahan tersebut menginstruksikan: (1) melakukan upaya penanggulangan kebakaran hutan dan lahan di seluruh wilayah Republik Indonesia yang meliputi kegiatan: (a) pencegahan terjadinya kebakaran hutan dan lahan; (b) pemadaman kebakaran hutan dan lahan; dan (3) penanganan pasca kebakaran hutan dan lahan. (2) mengefektifkan upaya penegakan hukum terhadap tindak pidana kebakaran hutan dan lahan sekaligus pembayaran ganti rugi sesuai dengan tingkat kerusakan atau akibat yang dibutuhkan untuk biaya rehabilitasi, pemulihan kondisi hutan dan lahan, atau tindakan lain yang diperlukan serta pengenaan sanksi administrasi sesuai ketentuan peraturan perundang-undangan.

Berkaitan dengan hal tersebut diatas telah dilakukan kegiatan sosialisasi pentingnya Penguatan Peningkatan Peran Serta dan Pemahaman Hukum bagi Masyarakat dan Pemangku Kepentingan dalam Pengendalian Kebakaran Hutan dan Lahan (Karhutla) di Desa Petapahan Kecamatan Tapung Kabupaten Kampar yang 
dilakukan pada tanggal 10 Agustus 2020 yang dihadiri oleh tokoh masyarakat, masyarakat, pejabat pemerintahan desa dan mahasiswa KKN Integrasi yang juga berada di Desa Petapahan Kecamatan Tapung Kabupaten Kampar sejak Juli 2020 hingga Agustus 2020. Sebelum dilakukannya sosialisasi terbuka di desa Petapahan telah dilakukan penyuluhan hukum kepada masyarakat selama bulan Juli dan bulan Agustus 2020 bersamaan dengan KKN Integrasi Mahasiswa Universitas Riau tahun 2020.

Kegiatan pengabdian berupa sosialisasi pentingnya Peningkatan Peran Serta dan Pemahaman Hukum bagi Masyarakat dan Pemangku Kepentingan dalam Pengendalian Kebakaran Hutan dan Lahan (Karhutla) di Desa Petapahan Kecamatan Tapung Kabupaten Kampar, menghasilkan:

1. Penyebarluasan informasi tepat guna, transformasi pengetahuan kepada masyarakat desa mengenai pentingnya Peningkatan Peran Serta dan Pemahaman Hukum bagi Masyarakat dan Pemangku Kepentingan dalam Pengendalian Kebakaran Hutan dan Lahan (Karhutla)

2. Pengendalian dan penanggulangan Kebakaran Hutan dan Lahan (Karhutla)

3. Meningkatnya pengetahuan masyarakat di Desa Petapahan akan pentingnya Penguatan Peningkatan Peran Serta dan Pemahaman Hukum bagi Masyarakat dan Pemangku Kepentingan dalam Pengendalian Kebakaran Hutan dan Lahan (Karhutla) di Desa Petapahan Kecamatan Tapung Kabupaten Kampar

4. Meningkatkan sikap peduli masyarakat terhadap hutan dalam rangka menjaga kelestarian hutan dan lingkungan yang ada di Desa Petapahan Kecamatan Tapung Kabupaten Kampar

5. Meningkatnya pengetahuan perangkat desa akan pentingnya menjaga hutan dan lahan dalam Pengendalian dan penanggulangan Kebakaran Hutan dan Lahan (Karhutla)

6. Sebagai masukan dalam pengambilan kebijakan mengenai Peningkatan Peran Serta dan Pemahaman Hukum bagi Masyarakat dan Pemangku Kepentingan dalam Pengendalian Kebakaran Hutan dan Lahan (Karhutla) di Desa Petapahan Kecamatan Tapung Kabupaten Kampar

Rekomendasi untuk perbaikan kondisi hutan dan lahan yang perlu dilakukan oleh masyarakat dan pemerintah daerah dalam rangka Penguatan Peningkatan Peran Serta dan Pemahaman Hukum bagi Masyarakat dan Pemangku Kepentingan dalam Pengendalian Kebakaran Hutan dan Lahan (Karhutla) di Desa Petapahan Kecamatan Tapung Kabupaten Kampar kedepan perlu peningkatan peran serta dari semua pihak untuk tetap menjaga hutan dan tidak membuka lahan dengan cara membakar. Hal tersebut bertujuan menjaga kelestarian hutan dan lingkungan. Harapan kedepan kebakaran hutan dan lahan dapat dicegah dan tidak lagi terjadi di Kabupaten Kampar dan Provinsi Riau pada umumnya jika kita semua mau sadar bahwa mencegah lebih baik daripada mengobati, mencegah kebakaran hutan lebih baik daripada memadamkan kebakaran hutan yang terlanjur berdampak dan memberikan kerugian besar bagi masyarakat.

Adapun indikator untuk melihat keberhasilan kegiatan ini adalah:

a. Adanya peningkatan pengetahuan dan pemahaman hukum peserta pengabdian tentang Pengendalian dan Penanggulangan Kebakaran Hutan dan Lahan (Karhutla) di Desa Petapahan Kecamatan Tapung Kabupaten Kampar. Kegiatan ini dilakukan dengan cara mengevaluasi peserta pengabdian dengan memberikan pertanyaan-pertanyaan terkait dengan materi pengabdian yang telah dilakukan.

b. Keberhasilan peserta dalam mendapatkan pengetahuan dan pemahaman tentang Pengendalian dan Penanggulangan Kebakaran Hutan dan Lahan (Karhutla).

c. Tingkat penerimaan materi pelatihan dapat dilihat dari kemampuan dan pemahaman peserta dalam menjawab pertanyaan yang diajukan oleh tenaga penyuluh.

d. Tingkat keterlibatan dari peserta dilihat dari jumlah dan variasi pertanyaan yang diajukan kepada tenaga penyuluh.

e. Dari tingkat partisipasi peserta pengabdian, dimana partisipasi peserta dapat dilihat dalam peserta pengabdian mengikuti kegiatan secara penuh dari awal hingga akhir kegiatan pengabdian.

f. Adanya kecocokan materi pengabdian dengan tujuan pengabdian.

g. Dari sisi ekonomi kegiatan ini berguna untuk masyarakat sekitar hutan agar dapat menikmati hasil hutan yang mereka kelola dengan harapan ada peningkatan ekonomi yang stabil dan menciptakan lapangan kerja bagi generasi mendatang.

Setelah kegiatan pengabdian dan penyuluhan berakhir, meningkatnya pemahaman dan pengetahuan serta mengertinya peserta pengabdian tentang Penguatan Peningkatan Peran Serta dan Pemahaman Hukum bagi Masyarakat dan Pemangku Kepentingan dalam Pengendalian Kebakaran Hutan dan Lahan (Karhutla) di Desa Petapahan Kecamatan Tapung Kabupaten Kampar. Serta kontribusi kebijakan yang direkomendasikan untuk peningkatan Peran Serta dan Pemahaman Hukum bagi Masyarakat dan Pemangku Kepentingan dalam 
Pengendalian dan Penanggulangan Kebakaran Hutan dan Lahan (Karhutla) di Desa Petapahan Kecamatan Tapung Kabupaten Kampar agar kedepan tidak terjadi lagi kebakaran hutan dan lahan di Kabupaten Kampar

\section{KESIMPULAN}

Kegiatan pengabdian berupa Penguatan Peningkatan Peran Serta dan Pemahaman Hukum bagi Masyarakat dan Pemangku Kepentingan dalam Pengendalian Kebakaran Hutan dan Lahan (Karhutla) di Desa Petapahan Kecamatan Tapung Kabupaten Kampar, menghasilkan: (1) Penyebarluasan informasi tepat guna dan transformasi pengetahuan kepada masyarakat desa mengenai pentingnya pencegahan dan pengendalian serta penanggulangan Kebakaran Hutan dan Lahan (Karhutla) di Desa Petapahan Kecamatan Tapung Kabupaten Kampar; (2) Meningkatnya pengetahuan dan pemahaman hukum masyarakat di Desa Petapahan akan pentingnya pencegahan dan pengendalian serta penanggulangan Kebakaran Hutan dan Lahan (Karhutla) di Desa Petapahan Kecamatan Tapung Kabupaten Kampar; (3) Meningkatkan sikap peduli masyarakat terhadap hutan dalam rangka menjaga kelestarian hutan dan lingkungan yang ada di Desa Petapahan Kecamatan Tapung Kabupaten Kampar (4) Meningkatnya pengetahuan perangkat desa akan pentingnya melakukan pencegahan dan pengendalian serta penanggulangan Kebakaran Hutan dan Lahan (Karhutla) di Desa Petapahan Kecamatan Tapung Kabupaten Kampar dan (5) Dari sisi ekonomi kegiatan ini berguna untuk masyarakat sekitar hutan agar dapat menikmati hasil hutan yang mereka kelola dengan harapan ada peningkatan ekonomi yang stabil dan menciptakan lapangan kerja bagi generasi mendatang

\section{UCAPAN TERIMA KASIH}

Terima kasih yang tak terhingga penulis ucapkan kepada Lembaga Penelitian dan Pengabdian kepada Masyarakat (LPPM) Universitas Riau yang telah memberikan kesempatan kepada penulis untuk melakukan pengabdian di tahun 2020 ini. Terima kasih yang tak terhingga juga penulis sampaikan kepada Bapak Kepala Desa dan aparatur Desa Petapahan yang banyak membantu dan menyediakan waktu, pikiran dan tenaga hingga selesainya pengabdian ini bersamaan dengan KKN Terintegrasi Mahasiswa Universitas Riau tahun 2020 di Desa Petapahan Kecamatan Tapung Kabupaten Kampar.

\section{DAFTAR PUSTAKA}

Desri Hunawan. 2016. Menyelesaikan Kebakaran Hutan dan Lahan (KARHUTLA) di Indonesia melalui "Jalan Pantas" atau "Jalan Pintas"? Seminar Nasional Hukum, 2(1) 277-292.

Jaringan Kerja Penyelamat Hutan Riau (Jikalahari) dalam 14 Tahun Melawan Monopoli Pengusaha Hutan dan Lahan, Catatan Hitam Tata Kelola Hutan dan Lahan di Riau 2002-2016, Pekanbaru, 2016.

Purbowaseso B. 2004. Pengendalian Kebakaran Hutan Suatu Pengantar. Jakarta: PT Rinetka Cipta.

Salim H.S. 2003. Dasar-dasar Hukum Kehutanan, Edisi Revisi. Sinar Grafika. Jakarta.

2018. Pengantar Hukum Sumber Daya Alam. Rajawali Press. Jakarta.

Walhi Riau. Refleksi 2018 dan Harapan 2019 menuju keadilan Ekologis di Provinsi Riau, Sebuah Catatan Akhir Tahun 2018 Walhi Riau atas Potret Penguasaan dan Pengelolaan Ruang-Ruang Hidup Rakyat, diterbitkan oleh Wahana Lingkungan Hidup Indonesia Eksekutif Daerah Riau - WALHI Riau, Pekanbaru. 